\title{
Interactive comment on "Combinatorial
} observation ionospheric characteristics during tropical cyclone Debbie passing eastern Australia in 2017 using GPS and ion sounder" by Fuyang Ke et al.

Jyh-Woei Lin

da520201@stust.edu.tw

Received and published: 7 November 2019

My comment is Section 5 for Conclusions The Conclusions can be shorter.

Interactive comment on Ann. Geophys. Discuss., https://doi.org/10.5194/angeo-2019-72, 2019. 